This document was prepared in conjunction with work accomplished under Contract No. DE-AC09-96SR18500 with the U. S. Department of Energy.

\title{
DISCLAIMER
}

This report was prepared as an account of work sponsored by an agency of the United States Government. Neither the United States Government nor any agency thereof, nor any of their employees, nor any of their contractors, subcontractors or their employees, makes any warranty, express or implied, or assumes any legal liability or responsibility for the accuracy, completeness, or any third party's use or the results of such use of any information, apparatus, product, or process disclosed, or represents that its use would not infringe privately owned rights. Reference herein to any specific commercial product, process, or service by trade name, trademark, manufacturer, or otherwise, does not necessarily constitute or imply its endorsement, recommendation, or favoring by the United States Government or any agency thereof or its contractors or subcontractors. The views and opinions of authors expressed herein do not necessarily state or reflect those of the United States Government or any agency thereof. 


\section{Task Technical and Quality Assurance Plan for 804 UG Organic Stripping}

T. B. Peters

M. R. Poirier

S. D. Fink

December 16, 2005

Savannah River National Laboratory

Washington Savannah River Company

Savannah River Site

Aiken, SC 29808

Prepared for the U.S. Department of Energy Under

Contract Number DE-AC09-96SR18500

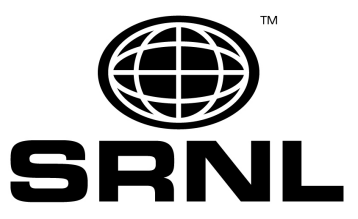




\section{DISCLAIMER}

This report was prepared for the United States Department of Energy under Contract No. DE-AC09-96SR18500 and is an account of work performed under that contract. Reference herein to any specific commercial product, or process, does not necessarily constitute or imply endorsement, recommendation, or favoring of same by Westinghouse Savannah River Company or by the United States Government or any agency thereof. The views and opinions of the authors expressed herein do not necessarily state or reflect those of the United States Government or any agency thereof.

\section{Printed in the United States of America}

Prepared For U.S. Department of Energy 


\section{REVIEWS AND APPROVALS}

\section{AUTHORS}

Thomes B. Peters

T. B. Peters, co-author

$$
\text { Hukn/PPein }
$$

M. R. Poirier, co-author
$1-4-2006$

Date

$1 / 4106$

Date

\section{APPROVALS}

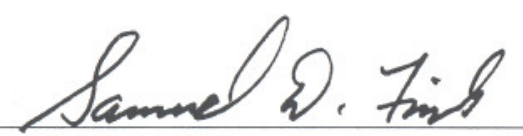

S. D. Fink, Manager, Process Chemistry and Science Group

SR. Ledu

S. R. Loflin, SRAL QA

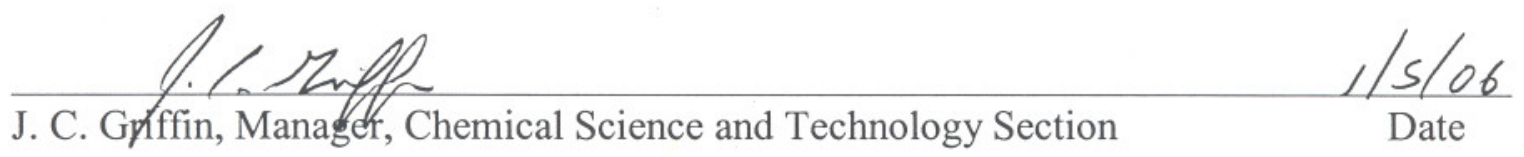

$1-4 \cdot 2006$

Date
J. C. Gpiffin, Manager, Chemical Science and Technology Section

Date

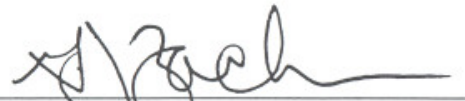

G. J. Zashmann, Chief Engineer, F-Area Closure Engineering

$1-5-06$

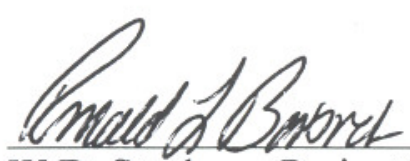

W.D. Stephens, Project Manager, Site D\&D

for

Date

$-5-\infty 6$

Date

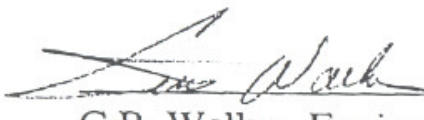

C.B. Walker, Environmental Compliance, Site D\&D

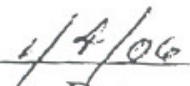

Date 


\section{LIST OF ACRONYMS}

$\begin{array}{ll}\text { AD } & \text { Analytical Development } \\ \text { DDI } & \text { Distilled deionized water } \\ \text { DOE } & \text { Department of Energy } \\ \text { DWPF } & \text { Defense Waste Processing Facility } \\ \text { HLW } & \text { High Level Waste } \\ \text { IC } & \text { Ion Chromatography } \\ \text { MST } & \text { Monosodium Titanate } \\ \text { SEM } & \text { Scanning Electron Microscope } \\ \text { SRS } & \text { Savannah River Site } \\ \text { SRNL } & \text { Savannah River National Laboratory } \\ \text { SPF } & \text { Saltstone Production Facility } \\ \text { SVOA } & \text { Semi-Volatile Organic Analysis } \\ \text { VOA } & \text { Volatile Organic Analysis }\end{array}$




\subsection{Introduction}

The SRS Decontamination and Decommissioning (D\&D) Organization is evaluating options to disposition the 804 underground tank which includes removal of the sludge from this tank and requested assistance from SRNL personnel to develop methods to effectively mobilize the sludge. However, analysis of the tank constituents has indicated a large quantity of flammable organics is present in the tank, intermixed with a large quantity ( $>1$ fissile mass of $\mathrm{Pu}^{239}$ ) of actinide-containing sludge. ${ }^{1}$ The presence of the organics presents a problem for disposition of the tank to the HLW tanks. A brainstorming session on 11-22-05 discussed several possible strategies to remove the organics from the tank. SRNL was tasked with performing tests to study the various organic removal options on Tank 804 sludge. $^{2}$

The objectives of this task follow.

- Experimentally simulate evaporation and steam stripping of the tank volatile components, and sample the distillate over time for the presence of organic species. CURRENTLY ON HOLD

- Evaluate filtration as a means of removing organic species after poisoning with Mn and the neutralization process (does organic remain with the solids?)

In addition, Site $\mathrm{D} \& \mathrm{D}$ has requested an evaluation of $\mathrm{Pu}$ distribution in the caustic adjusted 804 sludge without manganese addition at $\mathrm{pH} \bullet 14(1.0-1.2 \mathrm{M} \mathrm{NaOH}) .{ }^{3}$ CURRENTLY ON HOLD

\subsection{Task Description}

\subsection{Deliverables and Acceptance}

The deliverables include a technical report. The report will include a design check per WSRC Manual E7, procedure 2.60. The final reports will receive approval from selected personnel.

\subsection{Requirements}

All work will comply with established quality assurance procedures identified in this document. Approval of the document indicates acceptance of the plan.

\subsection{Prerequisites}

- CS\&T will complete the SRNL Conduct of Research and Development hazards assessment checklist prior to starting work.

- CS\&T will prepare and issue a Task Technical and Quality Assurance Plan that is approved by the appropriate SRNL Management, SRS D\&D Management, and SRNL-QAD. 
- CS\&T will ensure the M\&TE are calibrated prior to starting the work.

- CS\&T will arrange waste disposal.

\subsection{Activities}

\subsection{Approach}

SRS D\&D provided SRNL with a sample of the sludge from Tank 804. This material will be used in the evaporation, filtration, and $\mathrm{pH}$ adjustment tests. Even though there is a possibility that hazardous organo-mercurials will be formed, we are not explicitly trying to qualify or quantify them.

\subsubsection{Evaporation/Steam Stripping Tests (CURRENTLY ON HOLD)}

A 1-L batch of sludge will be prepared in the same manner that the sludge would be prepared for the tank farm.

- A mass of 804 sludge will be mass diluted 10:1 with DDI water

- Enough $\mathrm{Mn}\left(\mathrm{NO}_{3}\right)_{2}$ will be added to raise the solution to $1 \mathrm{M}$ in manganese $\left(40: 1 \mathrm{Mn}:{ }^{239} \mathrm{Pu}\right.$ by wt)

- The mixture will be $\mathrm{pH}$ adjusted to a free hydroxide concentration of $1.2 \mathrm{M}(\mathrm{pH} 14)$

The resulting adjusted slurry will be bottled, analyzed for $\mathrm{Mn}, \mathrm{Pu}, \mathrm{VOA}$ and SVOA in duplicate and set aside for use in the tests. Mixing the slurry will be done by shaking, the same method as used in WSRC-TR-2005-00540.

Researchers will assemble a distillation apparatus (Figure 1) for each of the tests.

The distillation flask will be a $500 \mathrm{~mL}$ working volume unit. For each test, $200 \mathrm{~mL}$ of adjusted slurry that was previously prepared will be added to the flask. This $200 \mathrm{~mL}$ level on the flask will be marked on the flask so the operator can determine if water should be added to the flask. We need to maintain a fixed volume in the flask to avoid distilling the sludge to dryness. As water leaves the distillation pot, water will be added back to the mark by the water addition funnel. The distillate catch flask will be marked at the $40 \mathrm{~mL}$ level so we know when to remove the catch flask.

SRNL envisions 2 tests in total. The first test is a short-term test run at different temperatures designed to find an adequate operating temperature. At first, the evaporation will be run at $60{ }^{\circ} \mathrm{C}$ until a single catch flask has been filled to the $40 \mathrm{~mL}$ mark, or for 8 hours, whichever comes first. The amount of distillate removed will be quantified, and the overheads sent forward to be analyzed for VOA and SVOA. After replacing the catch flask with an empty one, the evaporation temperature will be raised to $80^{\circ} \mathrm{C}$ for 8 hours or until the catch flask has been filled 
to the $40 \mathrm{~mL}$ mark. The amount of distillate removed will be quantified, and the overheads sent forward to be analyzed for VOA and SVOA. After replacing the catch flask with an empty one, the evaporation temperature will be raised to $100{ }^{\circ} \mathrm{C}$ for 8 hours or until the catch flask has been filled to the $40 \mathrm{~mL}$ mark. The amount of distillate removed will be quantified, and the overheads sent forward to be analyzed for VOA and SVOA. During the test, water will be added to the distillation pot as required to maintain a constant volume. Temperature monitoring will be provided by a thermocouple in the distillation pot (not shown in Figure 1). The contents of the distillation pot will be heated using a heating mantle. Each flask will then be set aside for later analyses. As a distillate catch flask is removed, the time from the beginning of distillation will be recorded. At the end of the test, the distillation pot will be sampled and sent forward to ADS for analyses.

Figure 1. Distillation Apparatus

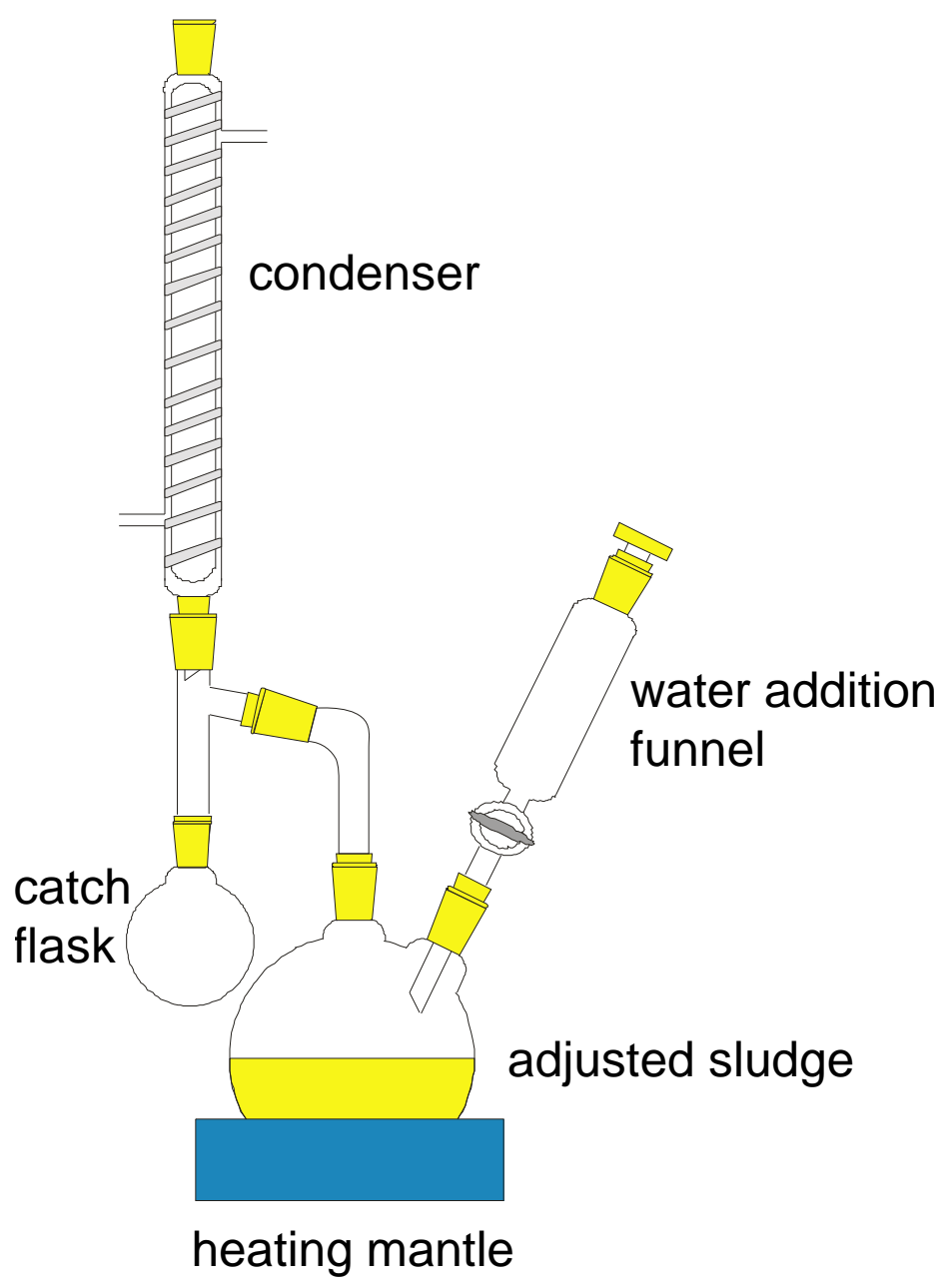


The second test will be run after the results of the first test are known. The most appropriate temperature $\left(60,80,100^{\circ} \mathrm{C}\right)$ will be chosen for the final test. This test will be run for 48 hours straight (requiring around the clock coverage), with water being added to the distillation pot as required. Alternatively, the distillation could be run in six 8 hour blocks to avoid excessive personnel costs. As a distillate catch flask is filled to the mark, it will be replaced by another empty one. The ratio of overheads to starting volume to obtain adequate evaporation will be determined. At the end of the tests, the distillation pot will be sampled and sent forward along with the distillate samples to ADS for analyses (VOA, SVOA, Mn and Pu analyses). The residual hold up material in the glass joints will be flushed, collected and sent forward to ADS for VOA and SVOA analyses. Finally, a sample of the distillation pot will taken for Scanning Electron Microscope (SEM) analysis.

\subsubsection{Filtration}

Researchers will prepare slurry as described in the evaporation tests. The slurry will contain 1 part Tank 804 sludge and 10 parts water. To this slurry they will add sufficient manganese nitrate to produce an adjusted slurry that is $1 \mathrm{M}$ in manganese. They will then add sufficient sodium hydroxide to adjust the $\mathrm{pH}$ to 14 . After agitating (shaking) this slurry, they will filter sub-samples through various pore size filters and submit the filtrate and rejected solids for organic analysis by VOA and SVOA and Pu and Mn.

\subsection{3 pH Adjustment Tests without Manganese Addition (CURRENTLY ON HOLD)}

Personnel will prepare a slurry containing Tank 804 sludge diluted 10:1 with water, then adjusted with nitric acid to $\mathrm{pH} 3$, and finally adjusted to $\mathrm{pH} 14$ with sodium hydroxide. After agitating by shaking, they will allow the slurry to settle overnight, collect samples from the top and bottom of the container, and analyze the samples by gamma ray spectroscopy for plutonium, by peroxide fusion/plutonium triphenyltrifluoroacetone scintillation analysis (PuTTA) for plutonium, and by volatile organic analysis (VOA)/semivolatile organic analysis (SVOA) for organic species. The researchers will take pictures before and after shaking the slurry bottle.

The solution will be remixed to suspend the solids, then the researchers will filter subsamples through various pore size filters and hold the filtrate and rejected solids samples for future analysis.

\subsection{Measurement and Analysis}

This task will use the following M\&TE:

- Balance calibration will reference weights traceable to NIST standards. 
Once a distillate flask is removed from the apparatus is will be set aside and sealed for later analysis. Once ready, the flask will be sent for Volatile Organic Analysis (VOA) and Semi-Volatile Organic Analysis (SVOA). At the end of each of the two tests, the distillation pot will be sampled and sent forward for VOA, SVOA, Pu, Mn and Ion Chromatography (IC) analyses. The intention is to determine the type and quantity of organic material that has distilled over as a rough function of time as well as assure that there is no large separation of plutonium from the manganese poison. Finally, the researchers will attempt to flush the glassware for residual hold-up material in the glass joints and this material forward to ADS for VOA and SVOA analyses.

The researchers will submit the filtrate and rejected solids for organic analysis by VOA and SVOA and plutonium analysis by PuTTa and will submit samples of the $\mathrm{pH}$ adjusted slurry for plutonium, manganese, and organic analyses by the methods described above.

\subsection{Documentation}

CS\&T researchers will record pertinent information in a controlled laboratory notebook in accordance with Manual L1, SRNL Procedures Manual, and Procedure 7.16. All reports will receive review and approval from SRNL line management as well as appropriate personnel within D\&D. A Savannah River National Laboratory researcher, not involved in the task, will conduct a design check of the report. This design check will include reviewing the input data, the analytical and experimental approach, mathematical calculations, assumptions, and the recommendations. 


\subsection{Risk Review}

The following table lists other risks and mitigating factors.

\begin{tabular}{lll} 
Risk Factor & Event & Mitigation \\
\hline Equipment & Failure & $\begin{array}{l}\text { Replacement or repair of item } \\
\text { with a potential delay. }\end{array}$ \\
& Operation Difficulty & $\begin{array}{l}\text { The distillation apparatus may be } \\
\text { difficult to manipulate in the } \\
\text { cells and this may impose a } \\
\text { working delay. }\end{array}$ \\
Personnel & Illness, vacation & $\begin{array}{l}\text { Primary and secondary } \\
\text { researchers identified. }\end{array}$ \\
& & \\
Facility & Outage (electrical, ventilation) & $\begin{array}{l}\text { Communicate with SRNL } \\
\text { operations so outages do not } \\
\text { interfere with testing. }\end{array}$
\end{tabular}

The data at $80^{\circ} \mathrm{C}$ and $100{ }^{\circ} \mathrm{C}$ may be predicated on the changes that occur at the early stages of the experiment. Hence, the rate or amount of organic removal at $80^{\circ} \mathrm{C}$ and $100^{\circ} \mathrm{C}$ will not reflect the initial rate at those conditions but will be impacted by the earlier [lower temperature] portion of the tests.

In addition, there is a risk that loss of organics due to heating and incomplete sampling may occur and hence the values may have wider variance and may not lead to closure on the overall organic balance.

Finally, the SVOA or VOA analyses may not accurately identify of quantitate the presence of methyl mercurials or dimethyl mercury, both of which can pose work hazards. 


\subsection{Schedule}

The following tentative schedule estimates the completion of deliverables for this task. We will accelerate this where possible.

Issue Task Plan

December 16, 2006

Complete filtration experimental and $\mathrm{pH}$ adjustment work

Complete evaporation experimental work

February 9, 2006

Issue report on filtration

February 22, 2006

Issue report on evaporation

March 13, 2006

March 31, 2006

The schedule for support of this task requires resource loading across all SRNL support activities. The lead investigator will provide information on schedule logic, task duration, needed resources, and resource constraints to the SRNL schedule development personnel.

\subsection{Safety and Quality Assurance}

The authors will complete the SRNL Conduct of Research and Development checklist prior to starting this task.

\subsection{Quality Assurance}

\section{Quality Assurance Checklist}

See Attachment 1.

\subsection{Documents Requiring Customer Approval}

The following documents require customer approval:

- Task Technical and Quality Assurance Plan

- Final Report

\subsection{Records}

The following items shall be designated records for this experimental program:

- The Task Technical Plan

- All applicable laboratory notebooks

- The final technical report

- Supporting documents as determined by the task leader (Tom Peters). 


\subsection{References}

${ }^{1}$ L. M. Chandler, A. R. Jurgensen, D. M. Missimer, "Tanks 804, 808, \& 809 Radiochemistry and Organic Data Compilation and Independent Technical Review", SRNL-ADS-2005-00463, July 29, 2005.

2 "Determine Effectiveness of Organic Removal from Slurried Tank 804 Sludge by Steam/Heating Stripping and Filtration”, R. A. Eubanks, December 6, 2005.

${ }^{3}$ M. R. Poirier, M. E. Stallings, P. R. Burket, and S. D. Fink, "Composition and Flow Behavior of F-Canyon Tank 804 Sludge following Manganese Addition and pH Adjustment", WSRC-TR2005-00540, November 30, 2005. 


\section{ATTACHMENT 1. QA CHECKLIST}

\section{WPT TASK QUALITY ASSURANCE PLAN CHECKLIST}

Task Technical Plan No: WSRC-RP-2005-01950, Rev. 0 Task Title: Task Technical and Quality Assurance Plan For 804 UG Organic Stripping Listed below are the sections of WSRC QA Manual (10). Check the $1 \mathrm{Q}$ sections applicable to your task. Also, check procedures CS\&T implements to control the task. This checklist identifies controls for task activities performed by CS\&T only. (Form Revised 11/30/2005)

\begin{tabular}{|c|c|c|c|}
\hline $\begin{array}{l}\text { WSRC 1Q } \\
\text { Section }\end{array}$ & $\begin{array}{l}\text { Applies } \\
\text { To Task }\end{array}$ & Procedures Implemented by CS\&T & $\begin{array}{l}\text { Procedure } \\
\text { Used }\end{array}$ \\
\hline \multirow[t]{2}{*}{ Organization } & \multirow[t]{2}{*}{$\mathrm{X}$} & $\begin{array}{l}\text { 1Q, QAP 1-1, Organization } \\
\text { L1, 1.02, SRTC Organization }\end{array}$ & $\begin{array}{l}\mathrm{X} \\
\mathrm{X}\end{array}$ \\
\hline & & 1Q, QAP 1-2, Stop Work & $\mathrm{X}$ \\
\hline \multirow[t]{6}{*}{ QA Program } & \multirow[t]{2}{*}{$\mathrm{X}$} & 1Q, QAP 2-1, Quality Assurance Program* & $\mathrm{X}$ \\
\hline & & $\begin{array}{l}\text { 1Q, QAP 2-2, Personnel Training \& Qual. } \\
\text { L1, 1.32, SRTC Read and Sign/Briefing Program }\end{array}$ & $\begin{array}{l}X \\
X\end{array}$ \\
\hline & $\mathrm{X}$ & $\begin{array}{l}\text { 1Q, QAP 2-3, Control of R\&D Activities* } \\
\text { L1, 7.10, Control of Technical Work }\end{array}$ & $\begin{array}{l}X \\
X\end{array}$ \\
\hline & \multirow[t]{3}{*}{$\mathrm{X}$} & L1, 7.16, Laboratory Notebooks and Logbooks & $\mathrm{X}$ \\
\hline & & $\begin{array}{l}\text { 1Q, QAP 2-4, Auditor/Lead Auditor Qual. \& Cert. } \\
\text { 1Q, QAP 2-5, Qual. \& Cert. of Independent Insp. } \\
\text { Personnel }\end{array}$ & \multirow{2}{*}{$\begin{array}{l}\text { NA for } \\
\text { CS\&T } \\
\text { NA for } \\
\text { CS\&T }\end{array}$} \\
\hline & & $\begin{array}{l}\text { 1Q, QAP 2-7 QA Program Req. for Analytical } \\
\text { Measurement Systems }\end{array}$ & \\
\hline Design Control & & $\begin{array}{l}\text { 1Q, QAP 3-1, Design Control } \\
\text { L1, 7.10, Control of Technical Work }\end{array}$ & \\
\hline $\begin{array}{l}\text { Procurement } \\
\text { Document } \\
\text { Control }\end{array}$ & & $\begin{array}{l}\text { 1Q, QAP 4-1, Procurement Document Control } \\
\text { E7, 3.10, Determination of Guality Requirements for } \\
\text { Procured Items } \\
7 \mathrm{~B}, 3 \mathrm{E} \text { (for reference only) }\end{array}$ & \\
\hline $\begin{array}{l}\text { Instructions, } \\
\text { Procedures } \\
\text { and Drawings }\end{array}$ & $\mathrm{X}$ & $\begin{array}{l}\text { 1Q, QAP 5-1, Instructions, Procedures, \& Drawings } \\
\text { E7, 2.30, Drawings } \\
\text { L1, 1.01, SRNL Procedure Administration }\end{array}$ & $\begin{array}{l}\mathrm{X} \\
\mathrm{X}\end{array}$ \\
\hline Document Control & $\mathrm{X}$ & $\begin{array}{l}\text { 1Q, QAP 6-1, Document Control } \\
\text { 1B, MRP 3.32, Document Control }\end{array}$ & $\begin{array}{l}\mathrm{X} \\
\mathrm{X}\end{array}$ \\
\hline \multirow[t]{2}{*}{$\begin{array}{l}\text { Control of } \\
\text { Purchased Items } \\
\text { and Services }\end{array}$} & & $\begin{array}{l}\text { 1Q, QAP 7-2, Control of Purchased Items \& } \\
\text { Services } \\
\text { 7B \& 3E (for reference only) } \\
\end{array}$ & \\
\hline & & $\begin{array}{l}\text { 1Q, QAP 7-3, Com. Grade Item Dedication } \\
\text { E7, 3.46, Replacement Item Evaluation/Com- } \\
\text { mercial Grade Dedication }\end{array}$ & \\
\hline $\begin{array}{l}\text { Identification \& } \\
\text { Control of Items }\end{array}$ & $\mathrm{X}$ & 1Q, QAP 8-1, ID and Control of Items* & $\mathrm{X}$ \\
\hline
\end{tabular}


WSRC-RP-2005-01950, Rev 0

\begin{tabular}{|c|c|c|}
\hline \multirow{4}{*}{$\begin{array}{l}\text { Control of } \\
\text { Processes }\end{array}$} & 19, QAP 9-1, Control of Processes & $\begin{array}{l}\text { NA for } \\
\text { CS\&T }\end{array}$ \\
\hline & 1Q, QAP 9-2, Control of Nondestructive Exam. & $\begin{array}{l}\text { NA for } \\
\text { CS\&T }\end{array}$ \\
\hline & 1Q, QAP 9-3, Control of Welding \& Other Joining Proc. & $\begin{array}{l}\text { NA for } \\
\text { CS\&T }\end{array}$ \\
\hline & $\begin{array}{l}\text { 1Q, QAP 9-4, Work Processes } \\
1 \mathrm{Y}, 8.20 \text {, Work Control Procedure }\end{array}$ & \\
\hline
\end{tabular}

\begin{tabular}{|c|c|c|c|}
\hline Inspection & & $\begin{array}{l}\text { 1Q, QAP 10-1, Inspection } \\
\mathrm{L} 1,8.10, \text { Inspection }\end{array}$ & $\begin{array}{l}\text { NA for } \\
\text { CS\&T }\end{array}$ \\
\hline Test Control & & $\begin{array}{l}\text { 1Q, QAP } 11-1 \text {, Test Control (applies to CS\&T only for } \\
\text { acceptance testing; R\&D test activities are controlled } \\
\text { by } 1 \mathrm{Q}, \mathrm{QAP} 2-3 \text { ) }\end{array}$ & \\
\hline \multirow{3}{*}{$\begin{array}{l}\text { Control of } \\
\text { Measuring \& Test } \\
\text { Equipment }\end{array}$} & \multirow[t]{3}{*}{$\mathrm{X}$} & 1Q, QAP 12-1, Control of Measuring \& Test Equipment & $\mathrm{X}$ \\
\hline & & $\begin{array}{l}\text { 1Q, QAP 12-2, Control of Installed Process } \\
\text { Instrumentation }\end{array}$ & \\
\hline & & $\begin{array}{l}\text { 1Q, QAP 12-3, Control \& Calibration of Radiation } \\
\text { Monitoring Equipment }\end{array}$ & \\
\hline $\begin{array}{l}\text { Packaging, } \\
\text { Handling, } \\
\text { Shipping \& } \\
\text { Storage }\end{array}$ & & 19, QAP 13-1, Pkg., Handling, Ship. \& Storage* & \\
\hline $\begin{array}{l}\text { Inspection, Test, } \\
\text { and } \\
\text { Operating Status }\end{array}$ & & 1Q, QAP 14-1, Inspection, Test, \& Operating Status* & \\
\hline $\begin{array}{l}\text { Control of } \\
\text { Nonconforming } \\
\text { Items \& Activities }\end{array}$ & $\mathrm{X}$ & 1Q, QAP 15-1, Control of Nonconforming Items* & $\mathrm{X}$ \\
\hline $\begin{array}{l}\text { Corrective Action } \\
\text { System }\end{array}$ & $\begin{array}{l}\mathrm{X} \\
\mathrm{X}\end{array}$ & $\begin{array}{l}\text { 1Q, QAP 16-3 Corrective Action Program } \\
\text { 1.01, MP 5.35, Corrective Action Program }\end{array}$ & $\mathrm{X}$ \\
\hline QA Records & $\mathrm{X}$ & $\begin{array}{l}\text { 13, QAP 17-1, QA Records Management* } \\
\text { L1, 7.16, Laboratory Notebooks and Logbooks }\end{array}$ & $\begin{array}{l}\mathrm{X} \\
\mathrm{X}\end{array}$ \\
\hline \multirow[t]{5}{*}{ Audits } & \multirow[t]{5}{*}{$\mathrm{X}$} & 13, QAP 18-2, Surveillance & \\
\hline & & 19, QAP 18-3, QA External Audits & \\
\hline & & $\begin{array}{l}\text { 1Q, QAP 18-4, Management Assessment Program } \\
\text { 12Q, Assessment Manual }\end{array}$ & \\
\hline & & 13, QAP 18-6, Quality Assurance Internal Audits & \\
\hline & & 1Q, QAP 18-7, Quality Assurance Supplier Surveillance & \\
\hline $\begin{array}{l}\text { Quality } \\
\text { Improvement }\end{array}$ & $\mathrm{X}$ & 1Q, QAP 19-2, Quality Improvement* & $\mathrm{X}$ \\
\hline $\begin{array}{l}\text { Software Quality } \\
\text { Assurance }\end{array}$ & & $\begin{array}{l}\text { 1Q, QAP 20-1, Software QA } \\
\text { L1, 8.20, Software Management \& QA }\end{array}$ & \\
\hline $\begin{array}{l}\text { Environmental } \\
\text { QA }\end{array}$ & & $\begin{array}{l}\text { 19, QAP 21-1, Quality Assurance Requirements for } \\
\text { the Collection and Eval. of Environmental Data }\end{array}$ & $\begin{array}{l}\text { NA for } \\
\text { CS\&T }\end{array}$ \\
\hline
\end{tabular}


WSRC-RP-2005-01950, Rev 0

Exceptions/Additions-Procedures identified on the checklist with an asterisk (*) are supplemented by a SRNL clarification in L1, 8.02, "SRNL QA Program Clarifications". WSRC-IM-2002-00011, "Technical Report Design Check Guidelines," will be used to help ensure the quality and consistency of the technical reviewer process for technical reports produced by SRNL Waste Treatment Technology. 